\title{
RESIDUAL EFFECT OF TWO Bacillus thuringiensis VAR. israelensis PRODUCTS ASSAYED AGAINST Aedes aegypti (DIPTERA: CULICIDAE) IN LABORATORY AND OUTDOORS AT RIO DE JANEIRO, BRAZIL
}

\author{
José Bento Pereira LIMA(1), Nilson Vieira de MELO(2) \& Denise VALLE(1)
}

\begin{abstract}
SUMMARY
Resistance of the dengue vector to temephos stimulated its substitution for Bacillus thuringiensis var. israelensis (Bti) since 2001 in Brazil. The persistence of the two Bti formulations employed at that time by the Health Ministry, Vectobac G and Aquabac $\mathrm{G}$, was assayed under laboratory and outdoor conditions. Both formulations were tested at $0.2 \mathrm{~g} / 10$ liters of water, the same concentration applied in the field for vector control. The tests were done against Ae. aegypti third instar larvae (Rockefeller strain). In the laboratory, Vectobac $\mathrm{G}$ and Aquabac $\mathrm{G}$ caused at least $95 \%$ mortality until 101 and 45 days after treatment, respectively. In the outdoor assays, test containers of different materials were treated with either formulation and placed in a shaded area. Larvae were introduced each 3-6 days and mortality was recorded 24 and 48 hours later. In the first set of assays, performed in June 2001, mortality levels of $70 \%$ or more were attained for $2-5$ weeks for both formulations in all containers. The exception was for the iron one that rusted, resulting in low mortality after seven days. In the second set of assays (August 2001), 70\% mortality was attained for just 1-2 weeks for all the containers and both formulations.
\end{abstract}

KEYWORDS: Aedes aegypti; Bacillus thuringiensis var. israelensis; Insecticide; Biological control.

\section{INTRODUCTION}

Aedes aegypti (L., 1762) is the major vector of dengue and dengue hemorrhagic fever and represents a significant public health problem. In the tropics two billion persons are considered to be at risk of dengue virus infection. Many dengue control programs use organophosphate (OP) insecticides to reduce vector densities, including temephos in domestic water containers and malathion, fenthion and fenitrothion for residual or space sprayings ${ }^{9}$.

The rapid increase in mosquito resistance to various chemical insecticides and the growing public concern over environmental pollution has resulted in the development of alternatives for mosquito control, such as the use of the biological agent Bacillus thuringiensis var. israelensis $(B t i)^{7}$. This entomopathogen acts on susceptible insect larvae after ingestion of the insecticidal crystalline protein (ICP) spore complex. In the midgut, the ICP-spore is dissociated to their protoxins and activated by gut proteases, inducing the arrest of feeding and leading to larval death ${ }^{2}$.

Different authors point to the effectiveness of Bti against several mosquito species and to its safety to the environment ${ }^{8,10,14,21}$. Laboratory bioassays and field applications of Bti confirmed activity against several black flies and mosquito species ${ }^{11,12,16,20}$. This entomopathogen has been used by the German Mosquito Control Association since 1981, and has successfully controlled mosquitoes in an area of approximately $500 \mathrm{~km}^{2}$ in the Upper Rhine valley, through the application of different Bti formulations $\mathrm{s}^{4,5}$.

In 2000, the Brazilian Dengue Control Program (PNCD) identified resistance of several Ae. aegypti populations, mainly in Rio de Janeiro State, to several organophosphates including temephos, the sole larvicidae employed in the country against this mosquito ${ }^{15}$. As a consequence, new local vector control strategies are being defined since then. Since January 2001, in Rio de Janeiro State, Bti products have been used as larvicides instead of temephos. The present study evaluated the residual effect of two Bti formulations (Aquabac G and Vectobac G) first used by the PNCD to replace temephos for the control of Ae. aegypti in some Brazilian municipalities. In the experiments conducted at the laboratory and in outdoors assays we used the same amount of $B t i$ formulations applied in the field against Ae. aegypti.

\section{MATERIAL AND METHODS}

Mosquitoes: Ae. aegypti late third instar larvae $\left(\mathrm{L}_{3}\right)$ of the Rockefeller strain were used in all assays. In order to induce

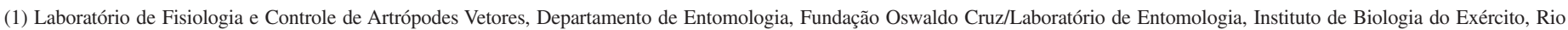
de Janeiro, RJ, Brazil.

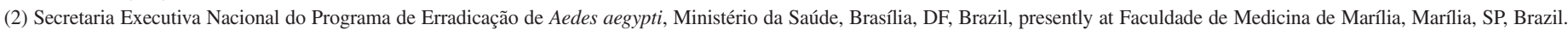

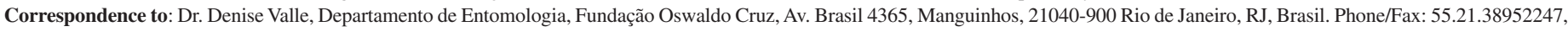
55.21.25806598. E-mail: dvalle@ioc.fiocruz.br 
synchronous larval emergence, eggs were immersed in dechlorinated water for one hour. Hamster food (Purina, Paulínia, SP) was supplied daily to feed the larvae.

Bti products: Aquabac G (200 ITU, Becker Microbials Products Inc., Florida, USA, lot $n^{\circ}$ 010501) and Vectobac G (200 ITU, Abbott Laboratórios do Brasil Ltda., Illinois, USA, lot $n^{\circ}$ 6419N801), were tested ( $0.2 \mathrm{~g} / 10$ liters of tap water), both consisting of the active ingredient impregnated in corncob granules.

Residual effect of the products at the laboratory: Three aluminum containers were filled with 40 liters of tap water. In the two experimental containers, $0.8 \mathrm{~g}$ of each product was added on the first day of the experiment. The third container served as a control and received only water. The laboratory temperature was recorded daily. The containers were kept covered, protected from light and no water was added during the tests.

For each test, performed weekly, 1,250 and $500 \mathrm{~mL}$ were removed from the experimental and control containers, respectively. Each test was performed with five replicates for experimental containers and two replicates for control ones. Each replicate consisted of a disposable plastic jar filled with $250 \mathrm{~mL}$ water from the containers, to which 20 $\mathrm{L}_{3}$ larvae were added. Mortality was scored 24 hours later.

Residual effect evaluation in an outside shaded area: A $12 \mathrm{~m}^{2}$ area in the district of Benfica, Rio de Janeiro was surrounded with wire netting to avoid access of domestic animals. An inclined opaque blue plastic cover, $3.4 \mathrm{~m}$ high on one side and $2.0 \mathrm{~m}$ high on the opposite side, installed to protect the area from rain, also provided partial shading. Twelve containers, three of plastic (200-liter capacity each), three of iron (200 liters each), three of cement (100 liters each) and three of asbestos (250 liters each), were randomly placed at the area. These containers were chosen among the mostly used by the local population to store water. One of each container type received Vectobac $\mathrm{G}$, one Aquabac $\mathrm{G}$, and the third one was used as a control. Plastic, iron, cement and asbestos containers were filled with respectively 150 , 150, 90 and 200 liters of tap water. Bti products were added at the concentration of $0.2 \mathrm{~g} / 10 \mathrm{~L}$. The containers remained covered with a nylon mesh to avoid egg laying by wild mosquitoes. Water was added to replace evaporation losses. Two evaluations were performed: in June and in August 2001.

Residual effect of the products was evaluated by exposing larvae to the containers' water every three to six days, inside devices consisting of polyvinylchloride pipes $7.5 \mathrm{~cm}$ in diameter $\mathrm{x} 50 \mathrm{~cm}$ in height (Fig. 1A). This device had the height of the water column inside the majority of the containers and enables the larvae access to different water depths. The test devices float freely inside the container by means of a Styrofoam plate (Fig. 1B). Two stripes of nylon mesh were placed laterally on the pipe to enable permanent contact of the larvae with the water. These mesh windows allow for free water exchange between the device and the container. Finally, the test devices can be easily manipulated, allowing for quick recovery of test larvae (Fig. 1C, D).

Each test device received 20 larvae and each assay consisted of five and three apparatus in the experimental and control containers, respectively. To validate the test devices, during the assays performed
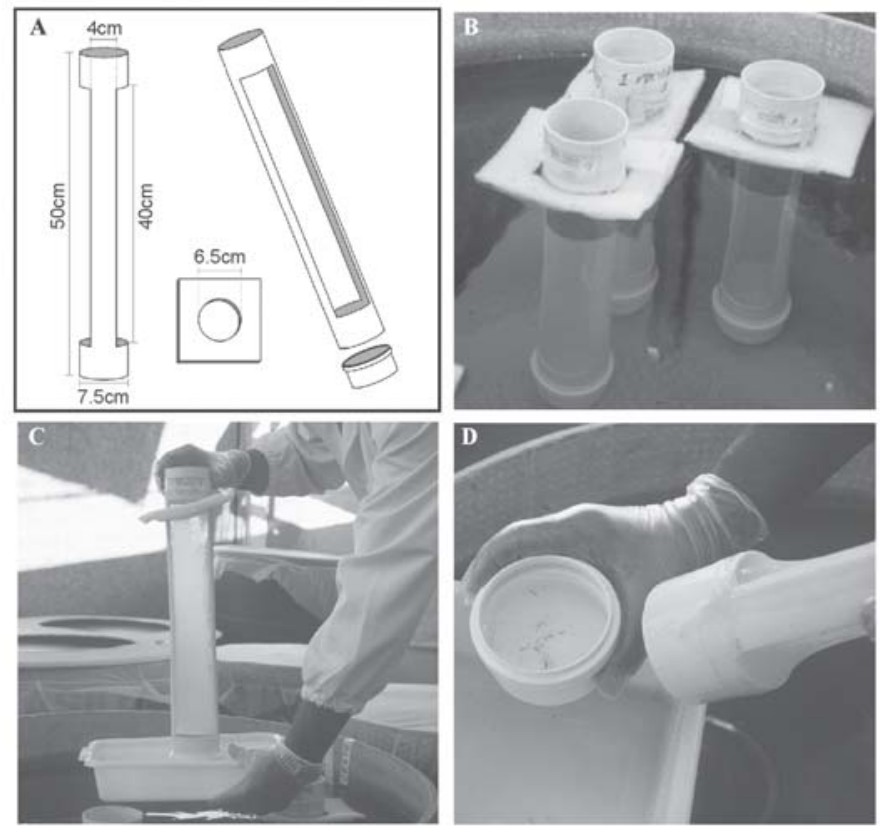

Fig. 1 - Test device used to follow larvae mortality in assays performed outdoors. (A) Scheme of the test apparatus dimensions and format. (B) Detail of the test devices floating in one container. (C) View of one test device being removed from the container. (D) Removal of the bottom lid containing larvae from the container.

in June for both Vectobac G and Aquabac G, 50 larvae were simultaneously placed directly into each container. Mortality was scored after 24 hours.

Evaluation of larvae mortality was done as follows: all larvae placed directly in the containers, dead or alive, were individually transferred to a white plastic basin with the aid of a transfer pipette and counted. To count larvae in the test devices, the whole apparatus were lifted to drain excess water and the bottom lids were loosened over a plastic basin. Larvae were then counted directly inside the lid or after transferring to the basin (Fig. 1C, D). Persistence tests continued until mortality in the experimental containers dropped to less than $50 \%$.

Analysis of data: Data were analyzed by one-way ANOVA/ Newman Keuls multiple comparison test ${ }^{18}$ to determine differences between Vectobac $\mathrm{G}$ and Aquabac $\mathrm{G}$ in all the assays. In the field simulation tests, comparisons between the test device and larvae kept directly in the containers and comparisons among the various types of containers were also performed.

\section{RESULTS}

Product residual effect under laboratory conditions: Previous comparison of mortality after 24 and 48 hours of exposure did not reveal any significant difference $(\mathrm{p}>0.05)$. Therefore, just 24 hours exposure data were considered for analysis. Temperature in the laboratory varied from 20 to $27^{\circ} \mathrm{C}$ throughout the test period. Residual evaluation of both Bti products at laboratory conditions showed that Aquabac $\mathrm{G}$ caused at least $95 \%$ mortality up to 45 days (Fig. 2). Thereafter, the efficiency of Aquabac G dropped abruptly, reaching 


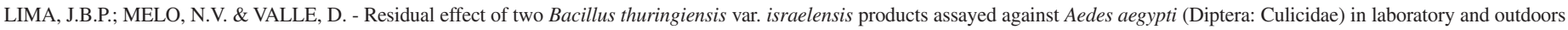
at Rio de Janeiro, Brazil. Rev. Inst. Med. trop. S. Paulo, 47(3): 125-130, 2005.

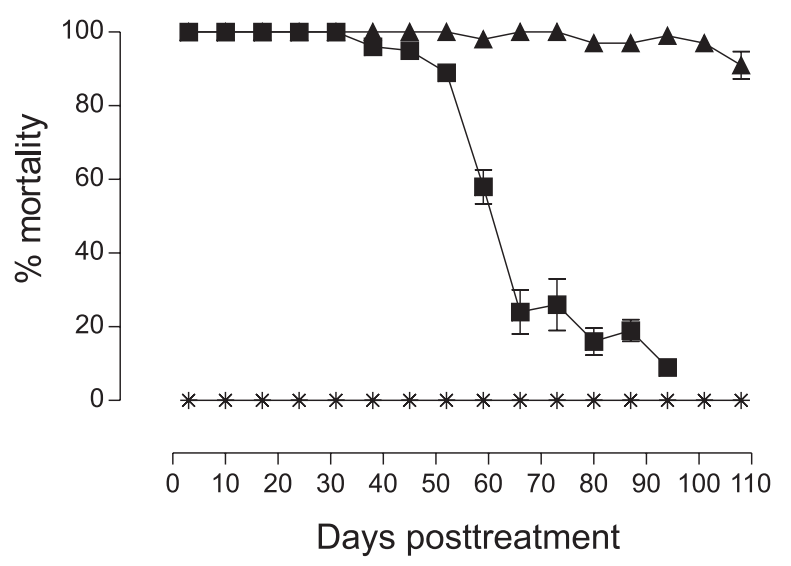

Fig. 2 - Persistence of two Bti products (Aquabac G and Vectobac G) in laboratory conditions. Comparison of larvae mortality after exposure to Aquabac $\mathrm{G}(\boldsymbol{\square})$ and Vectobac $\mathrm{G}(\boldsymbol{\Delta})$; (*) refer to the control container.
$24 \%$ mortality 66 days after the beginning of the test. In contrast, Vectobac $\mathrm{G}$ caused high mortality levels (>95\%) up to 101 days, when the experiment was interrupted. Statistical analysis showed highly significant differences between both products when the whole test period was considered $(\mathrm{p}<0.001)$.

Product residual effect in containers placed outdoors: Two evaluations were performed: in June 2001, when temperature ranges were $18.7-34.6{ }^{\circ} \mathrm{C}$ (mean of $28.1{ }^{\circ} \mathrm{C}$ ) and in August 2001 (mean temperature of $30.0^{\circ} \mathrm{C}$ ). Results obtained with the test devices were equivalent to those obtained with larvae placed directly in the containers $(\mathrm{p}>0.05)$ (Fig. 3).

In the assay performed in June 2001, larvae mortality in the containers made of cement and asbestos was greater than $95 \%$ until 24 days for both $B t i$ products. In the plastic containers, mortality was greater than $95 \%$ until 13 days and until seven days for Vectobac $G$ and Aquabac G, respectively. For the iron containers mortality attained

\section{A}

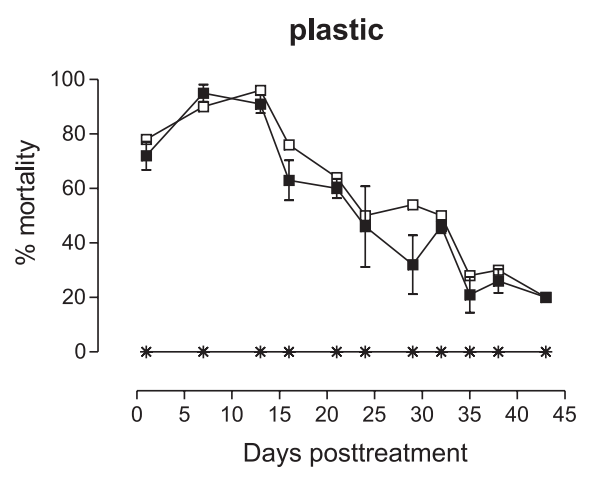

C
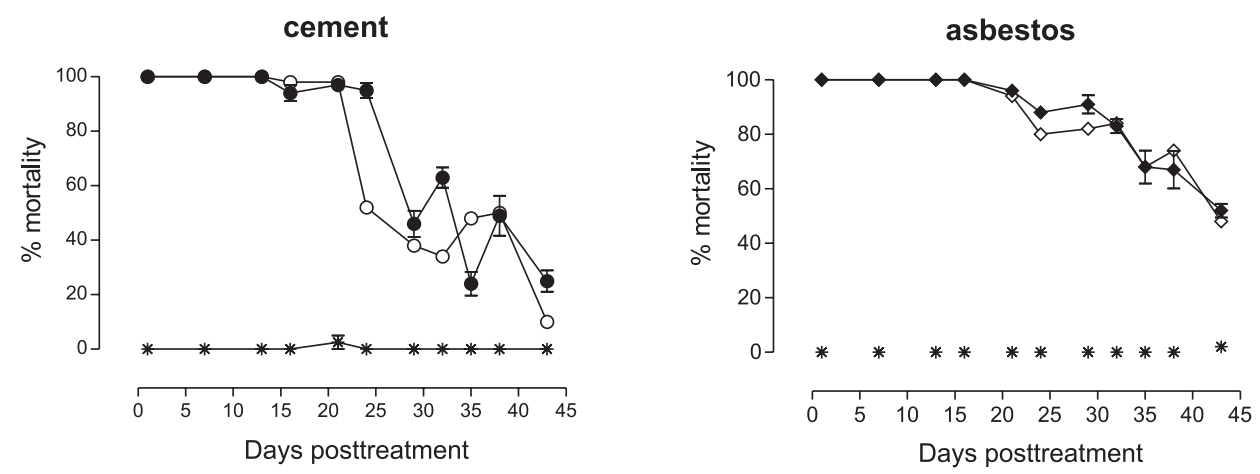

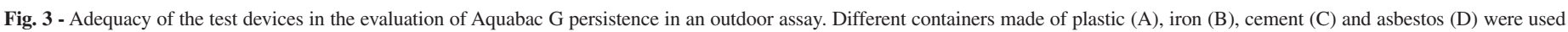

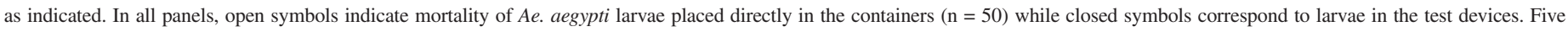

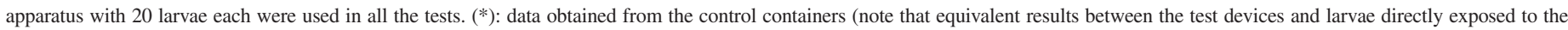
containers were obtained for Vectobac G). 
less than $80 \%$ on the seventh day for both products (Fig. 4A, B). In this test, significant differences among the containers were noted for Aquabac $\mathrm{G}$ in the asbestos containers when compared to plastic ( $\mathrm{p}<$ $0.01)$ and iron $(\mathrm{p}<0.05)$ containers. When Vectobac $\mathrm{G}$ was considered, significant differences were shown in iron containers compared to the plastic $(\mathrm{p}<0.05)$, cement $(\mathrm{p}<0.01)$ and asbestos $(\mathrm{p}<0.01)$ ones. In the iron containers, a large amount of rust was detected a few days after the beginning of the test. This showed to be the reason for the lower residual effect of both Bti products in these containers. In all other containers treated with Vectobac G mortality of $70 \%$ or higher was attained for three to four weeks. Aquabac $\mathrm{G}$ induced equivalent levels of mortality during two to five weeks.

Before starting the tests in August, 2001, the iron containers were painted to avoid rust. At that time, no significant differences were noted between Vectobac G and Aquabac G (Fig. 4C, D) or among the various containers $(p>0.05)$. In this test, residual effect of both Bti products was low: mortality dropped to less than $70 \%$ after one to two weeks in all cases.

\section{DISCUSSION}

Although $B t i$ is recognized as an efficient bioinsecticide, adequate formulations that exhibit high persistence in the field are not yet available. Laboratory tests show that Bti persistence can last for 100 days ${ }^{12}$. However, field assays show a residual effect of Bti formulations for two to three weeks $s^{3,13,17}$. Several environmental factors influence $B t i$ effectiveness in mosquito control programs, including high temperature and exposure to the sunlight ${ }^{12,13}$. Accordingly, unless containers of various types have been used in the present study, major differences were only noted between both tests, performed in June and in August 2001, probably due to temperature differences. Similarly to other authors, we found a residual effect of one to five weeks in the outdoors assays for the Bti formulations tested. In opposition, when applied at the same
A

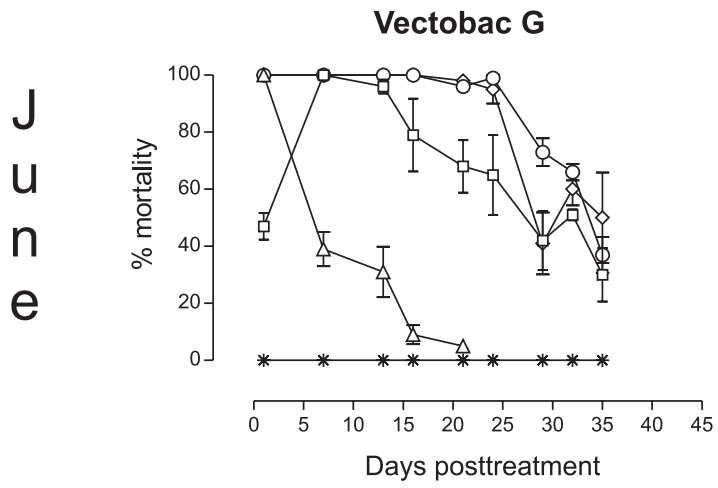

Days posttreatment

C

Vectobac G

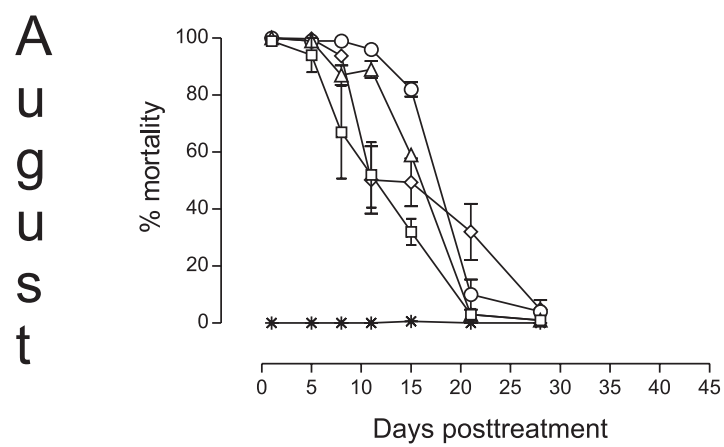

B

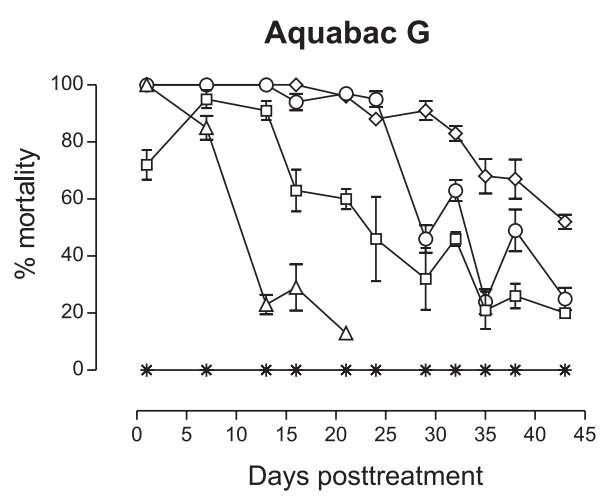

D

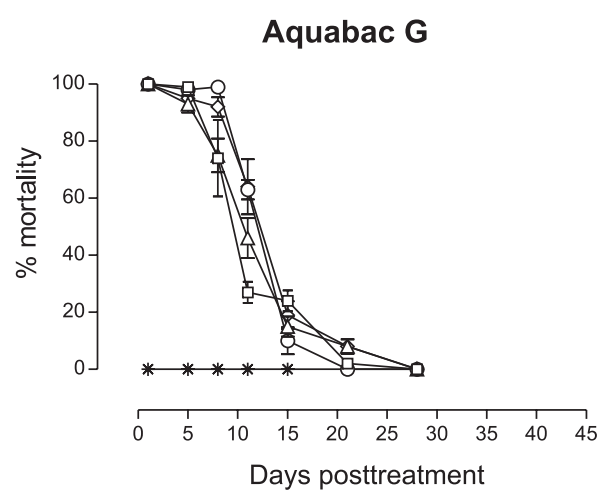

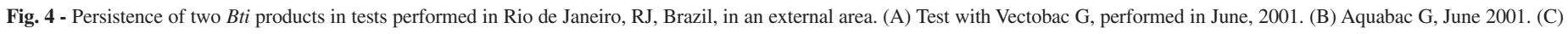

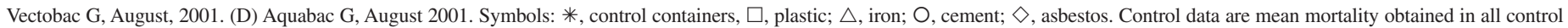
containers. Mortality was scored in five and three replicas (of 20 larvae each) for experimental and control conditions, respectively. 


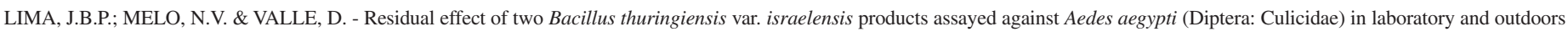
at Rio de Janeiro, Brazil. Rev. Inst. Med. trop. S. Paulo, 47(3): 125-130, 2005.

concentration at laboratory conditions, the two products exhibited higher residual effect, Vectobac G being at least twice as "persistent" as Aquabac G (95\% mortality up to 101 and 45 days, respectively).

A variety of ways of exposing mosquito larvae to Bti in field and semi-field evaluation tests can be found in the literature. ALI et al. ${ }^{1}$ placed larvae directly in big laundry tubes containing 40 liters water. BROWN et al. ${ }^{6}$ assessed the efficacy of a Bti formulation in salt-marsh pools exposing larvae inside $100 \mathrm{~cm}$-diameter web floating cylinders. Scoring larvae over such a large area can be a difficult process. SU \& MULLA ${ }^{19}$ put larvae inside several $0.4 \mathrm{~m}^{3}$ fiberglass test tubes, placed on a concrete slab, a procedure that occupies much physical place. The test devices described here are of simple manipulation, allowing for the quick recovery of larvae. Although Aedes larvae are said to feed by gathering particles deposited on the bottom, mortality obtained for both formulations was equivalent when larvae were placed in the test devices or directly exposed to the containers. This suggests that the test devices can be used to obtain quick information concerning the persistence of a biolarvicide.

It should be noticed that during the tests, no water withdrawal was performed, except for replacement of evaporation losses. This procedure differs from the real situation, because water is constantly being removed and replaced in the containers by dwellers.

In summary, our data indicate that the residual effect of Vectobac $\mathrm{G}$ and Aquabac $\mathrm{G}$ does not differ from what has been found by other authors with Bti products. Additionally, the climate conditions of Rio de Janeiro may have contributed to a lower persistence when containers were placed outdoors. Presently other Bti formulations are being tested against recently established colonies derived from Brazilian Ae. aegypti populations.

\section{RESUMO}

\section{Efeito residual de duas formulações de Bacillus thuringiensis var. israelensis sobre Aedes aegypti (Diptera: Culicidae) em condições de laboratório e em simulado de campo, no Rio de Janeiro, Brasil}

Resistência do vetor de dengue, Aedes aegypti, a temephos estimulou sua substituição por Bacillus thuringiensis var. israelensis (Bti) desde 2001 no Brasil. A persistência de duas formulações de Bti empregadas naquele ano pelo Ministério da Saúde, Vectobac G e Aquabac G, foi testada em condições externas e de laboratório. Ambas formulações foram testadas a 0,2 g/10 litros de água, a mesma concentração recomendada para o controle do vetor no campo. Os testes foram realizados com larvas de Ae. aegypti de terceiro estádio (linhagem Rockefeller). No laboratório, Vectobac G e Aquabac G induziram pelo menos $95 \%$ de mortalidade até 101 e 45 dias depois do tratamento, respectivamente. Nos testes externos, recipientes de diferentes materiais foram tratados com cada formulação e colocados em local coberto. Larvas foram introduzidas a cada três a seis dias e a mortalidade foi observada após 24 e 48 horas. Na primeira série de ensaios (junho 2001) mortalidade de $70 \%$ ou mais foi alcançada por duas a cinco semanas em todos os recipientes. A exceção foi o recipiente de metal que oxidou, resultando em baixos níveis de mortalidade após sete dias. Na segunda série de ensaios (agosto 2001), 70\% de mortalidade foi obtida por apenas uma a duas semanas para todos os recipientes e para ambas formulações.

\section{ACKNOWLEDGEMENTS}

The authors thank Marcella Pereira da Cunha, Gilberto Couto Alcântara and Henrique Marques da Costa Ramon for technical assistance and the Instituto de Biologia do Exército for laboratory facilities. This work was supported by Fundação Oswaldo Cruz, Programa de Erradicação do Aedes aegypti (PEAa), Financiadora de Estudos e Projetos do Estado do Rio de Janeiro (FAPERJ), Conselho Nacional de Desenvolvimento Científico e Tecnológico (CNPq) and Fundação Nacional de Saúde (FUNASA).

\section{REFERENCES}

1. ALI, A.; XUE, R.; LOBINSKE, R. \& CARANDANG, N. - Evaluation of granular corncob formulations of Bacillus thuringiensis serovar israelensis against mosquito larvae using a semi-field bioassay method. J. Amer. Mosq. Control Ass., 10: 492-495, 1994.

2. ARONSON, A.I. \& SHAI, Y. - Why Bacillus thuringiensis insecticidal toxins are so effective: unique features of their mode of action. FEMS Microbiol. Lett., 195: 1$8,2001$.

3. BATRA, C.P.; MITTAL, P.K. \& ADAK, T. - Control of Aedes aegypti breeding in desert coolers and tires by use of Bacillus thuringiensis var. israelensis formulation. J. Amer. Mosq. Control Ass., 16: 321-323, 2000.

4. BECKER, N. \& LUDWIG, M. - Investigations on possible resistance in Aedes vexans field populations after a 10-year application of Bacillus thuringiensis israelensis. J. Amer. Mosq. Control Ass., 9: 221-224, 1993.

5. BECKER, N. - Microbial control of mosquitoes: management of the upper Rhine mosquito population as a model programme. Parasit. today, 13: 485-487, 1997.

6. BROWN, M.D.; THOMAS, D.; WATSON, K. \& KAY, B.H. - Laboratory and field evaluation of efficacy of VectobBac ${ }^{\circledR} 12 \mathrm{AS}$ against Culex sitiens (Diptera: Culicidae) larvae. J. Amer. Mosq. Control Ass., 14: 183-185, 1998.

7. FEDERICI, B.A. - The future of microbial insecticides as vector control agents. J. Amer Mosq. Control Ass., 11: 260-268, 1995.

8. FLEXNER, J.L.; LIGHTHART, B. \& CROFT, B.A. - The effects of microbial pesticides on non-target, beneficial arthropods. Agricult. Ecosystem Environ., 16: 203-254, 1986.

9. GEORGHIOU, G.P.; WIRTH, M.C.; TRAN, H.; SAUME F. \& KNUDSEN, A.B. Potential for organophosphate resistance in Aedes aegypti (Diptera: Culicidae) in the Caribbean area and neighboring countries. J. med. Entomol., 24: 290-294, 1987.

10. GHARIB, A.H. \& HILSENHOFF, W.L. - Efficacy of two formulations of Bacillus thuringiensis var: israelensis (H-14) against Aedes vexans and safety to non-target macroinvertebrates. J. Amer. Mosq. Control Ass., 4: 252-255, 1988.

11. GOETTEL, M.S.; TOOHEY, M.K. \& PILLAI, J.S. - Laboratory bioassays of four formulations of Bacillus thuringiensis var. israelensis against Aedes polynesiensis, Ae. pseudoscutellaris and Aedes aegypti. Mosq. News, 42: 163-167, 1982.

12. IGNOFFO, C.M.; GARCIA, C.; KROHA, M.J.; FUKURA, T. \& COUCH, T.L. Laboratory tests to evaluate the potential efficacy of Bacillus thuringiensis var. israelensis for use against mosquitoes. Mosq. News, 41: 84-93, 1981.

13. KRAMER, V.L. - Efficacy and persistence of Bacillus sphaericus, Bacillus thuringiensis var. israelensis, and methoprene against Culiseta incidens (Diptera: Culicidae) in tires. J. econ. Entomol., 83: 1280-1285, 1990. 


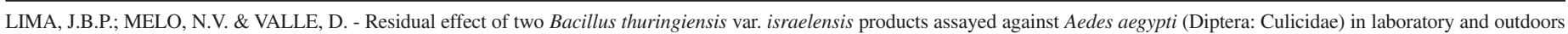
at Rio de Janeiro, Brazil. Rev. Inst. Med. trop. S. Paulo, 47(3): 125-130, 2005.

14. LACEY, L.A.; URBINA, M.J. \& HEITZMAN, C.M. - Sustained release formulations of Bacillus sphaericus and Bacillus thuringiensis (H-14) for control of containerbreeding Culex quinquefasciatus. Mosq. News, 44: 26-32, 1984.

15. LIMA, J.B.P.; PEREIRA DA-CUNHA, M.; SILVA Jr., R.C. et al. - Resistance of Aedes aegypti to organophosphates in several municipalities in the state of Rio de Janeiro and Espírito Santo, Brazil. Amer. J. trop. Med. Hyg., 68: 329-333, 2003.

16. MOLLOY, D. \& JAMNBACK, H. - Field evaluation of Bacillus thuringiensis var. israelensis as a black fly biocontrol agent and its effect on nontarget stream insects. J. econ. Entomol., 74: 314-318, 1981.

17. SKOVMAND, O. \& SANOGO, E. - Experimental formulations of Bacillus sphaericus and B. thuringiensis israelensis against Culex quinquefasciatus and Anopheles gambiae (Diptera: Culicidae) in Burkina Faso. J. med. Entomol., 36: 62-67, 1999.

18. SOKAL, R.R \& ROHLF, F.J. - Biometry: the principles and practice of statistics in biological research. 4. ed. New York, W.H. Freeman, 1994.
19. SU, T. \& MULLA, M.S. - Field evaluation of new water-dispersible granular formulations of Bacillus thuringiensis ssp. israelensis and Bacillus sphaericus against Culex mosquitoes in microcosms. J. Amer. Mosq. Control Ass., 15: 356-365, 1999.

20. SUN, C.N.; GEORGHIOU, G.P. \& WEISS, K. - Toxicity of Bacillus thuringiensis var. israelensis to mosquito larvae variously resistant to conventional insecticides. Mosq. News, 40: 614-618, 1980

21. YAP, H.H.; LEE, Y.W. \& ZAIRI, J. - Indoor thermal fogging against vector mosquitoes with two Bacillus thuringiensis israelensis formulations, Vectobac ABG 6511 waterdispersible granules and Vectobac 12AS liquid. J. Amer. Mosq. Control Ass., 18: 52-56, 2002.

Received: 30 August 2004.

Accepted: 5 April 2005 